\title{
Tallness is associated with risk of testicular cancer: evidence for the nutrition hypothesis
}

\section{K-P Dieckmann *,I, JT Hartmann ${ }^{2}$, J Classen ${ }^{3}$, R Lüdde $^{4}$, M Diederichs' and U Pichlmeier $^{5}$ for German Testicular Cancer Study Group ${ }^{6}$}

'Albertinen-Krankenhaus Hamburg, Klinik für Urologie, Hamburg, Germany; ${ }^{2}$ Klinik für Hämatologie, Onkologie, Immunologie, Rheumatologie und Pneumologie, Südwestdeutsches Tumorzentrum, Universitätsklinik Tübingen, Tübingen, Germany; ${ }^{3}$ Institut für Radio-Onkologie, St Vincentius Kliniken, Karlsruhe, Germany; ${ }^{4}$ Institut für Wehrmedizinalstatistik und Berichtswesen der Bundeswehr, Andernach, Germany; ${ }^{5}$ Institut für Medizinische Biometrie und Epidemiologie am Zentrum für Experimentelle Medizin, Universitätsklinikum Hamburg-Eppendorf, Hamburg, Germany

The pathogenesis of testicular germ cell tumours (GCTs) is potentially influenced by high-energy nutrition during infancy. As adult height is a proxy for childhood nutrition, we investigated the role of nutrition in GCT pathogenesis by comparing stature of patients with healthy men. In a matched case-control study, 64I5 patients with GCT were compared with healthy army conscripts ( $1: 6$ matching modus) with regard to height $(\mathrm{cm})$ and body mass index $\left(\mathrm{BMl} ; \mathrm{kg} / \mathrm{m}^{2}\right)$. Statistical analysis involved tabulation of descriptive height measures and BMI. Conditional logistic regression models were used to quantify the association of GCT with height, with odds ratios (OR) adjusted for BMI. The literature was searched for studies on stature in GCT patients. Body size is significantly associated with risk of GCT, very tall men $(>195 \mathrm{~cm})$ having a GCT risk of $\mathrm{OR}=3.35$ (95\% confidence intervals $(\mathrm{Cl})$ : 2.88-3.90; adjusted). Short stature is protective $(\mathrm{OR}=0.798 ; 95 \% \mathrm{Cl}: 0.68-0.93)$. Both histologic subgroups are associated with tallness. Of 16 previous reports, 7 were confirmative, 5 had null and 4 equivocal results. The association of stature with GCT risk accords with the nutrition hypothesis of GCT. This study expands the current view of GCT tumorigenesis by suggesting that high-calorie intake in childhood promotes GCT precursors originating in utero.

British Journal of Cancer (2008) 99, I5 I7- I52I. doi:I0.1038/sj.bjc.6604695 www.bjcancer.com

Published online 30 September 2008

(c) 2008 Cancer Research UK

Keywords: testicular cancer; body size; childhood nutrition; seminoma; non-seminoma; BMI

Adult stature results from a combination of genetic and environmental factors (Sinclair and Dangerfield, 1998). The most important environmental element impacting on childhood growth is nutrition (Gunnell et al, 2001). Attained adult height can thus be used as a biomarker for early childhood energy intake (Albanes et al, 1988). There is some indication for a positive association between adult height and overall risk of malignancy (Batty et al, 2006), although the data reported are inconsistent as yet (Giovannucci et al, 2004).

Testicular germ cell tumours (GCTs) are thought to originate in utero. Precursors of GCT, closely resembling primordial germ cells evolve in the primitive gonad, secondary to excess maternal oestrogen levels during embryogenesis (Dieckmann and Skakkebaek, 1999; Hoei-Hansen et al, 2005). Putatively, these precursors of malignancy may be promoted by factors acting during early childhood (Dieckmann and Pichlmeier, 2004), such as high-calorie nutrition. This assumption is mostly based on the observation that GCT incidence significantly decreased in post-war periods in Europe, when nutrition was mainly poor (Moller, 1993;

*Correspondence: Professor K-P Dieckmann, Albertinen-Krankenhaus, Urologische Abteilung, Suentelstrasse I Ia, D-22457 Hamburg, Germany; E-mail: DieckmannKP@t-online.de

${ }^{6}$ Project No AUO AH/33/02.

Received 21 July 2008; revised 22 August 2008; accepted 5 September 2008; published online 30 September 2008
Bray et al, 2006). Although, an association of GCT with tallness has often been postulated (Ehrengut et al, 1980), there are inconsistencies among the studies. In particular, methodological design was vastly different among the studies and some of the analyses were hampered by small sample size (Kleinteich and Marx, 1983; Whittemore et al, 1984). We have therefore, investigated the presumed association of GCT with height in a large patient sample and summarised previous data relating to this issue in the hope of resolving the question of tallness and GCT.

\section{MATERIALS AND METHODS}

This investigation was designed as a matched case-control study with 228 participating institutions (appendix). Accrual started in 2002 and was terminated by the end of 2005. Cases treated during 1995-2005 were eligible (Dieckmann, 2007). Roughly 60\% of the cases were enroled retrospectively. A total of 6415 patients were registered from all regions across Germany, ages ranging from 18 to 40 years. All were of Caucasian descent, and all had histologically confirmed testicular GCT, 58.4\% non-seminoma and $41.6 \%$ pure seminoma. Army conscripts of the German Army (Deutsche Bundeswehr) served as healthy controls. Data on national cohorts of conscripts born between 1965 and 1984 were supplied electronically by the Army Institute of Medical Statistics (Institut für Wehrmedizinalstatistik, Andernach), comprising 4357977 entries with anthropometric data of entire cohorts of 
young men aged 18-19 years examined by the German Army nation-wide during enrolment years 1985-2005.

The following anthropometric measures were recorded for each patient and control, respectively: Height $(\mathrm{cm})$, weight $(\mathrm{kg})$, and body mass index (BMI; $\mathrm{kg} / \mathrm{m}^{2}$ ), as well as the exact date of birth. Histology of GCT was noted (pure seminoma or non-seminoma). Measurements for controls were those taken at military enrolment, whereas those for patients were mainly self-reported. As final adult height is usually attained at the age of $18-19$ years, comparison of army conscripts with adult GCT patients is reasonable with respect to height. However, as body weight and BMI mostly continue to increase beyond age 19 (Mensink et al, 2005), these young army conscripts are no appropriate controls to compare with adult GCT patients. Accordingly, this analysis is limited to the role of adult height. Yet, data on BMI were recorded for purposes of adjustment in the course of statistical analysis.

For statistical comparison, a matching of patients with control persons according to exact date of birth was designed. In light of the minor variations regarding mean adult height among eastern and western regions in Germany, (Jaeger et al, 2001) we elected to employ a set of six individually matched control persons for each patient to overcome the potential confounding caused by regional variation. The final control population thus consisted of $n=38490$ participants. In cases where more than six subjects were available for control among the original database, a random selection was performed.

\section{Statistical analysis}

Matching and statistical analysis was accomplished by employing SAS software package (V.9. 1.3) on the Windows platform. First, a descriptive tabulation was performed regarding median height, 25th percentiles, 75th percentiles, as well as maximum and minimum height as found in the populations of GCT patients, controls, and in the subsets of seminoma and non-seminoma, respectively. For further detailed analysis, patients and controls were categorised with respect to height and BMI, respectively. Categories were $<170,170-174,175-179,180-184,185-189$, $190-194, \geqslant 195$ with regard to height $(\mathrm{cm})$, and $<20,20$ to $<25$, 25 to $<30, \geqslant 30$ with respect to BMI $\left(\mathrm{kg} / \mathrm{m}^{2}\right)$. As the median height of German males aged 18-40 years currently ranges from 176 to $179 \mathrm{~cm}$, the height category $175-179 \mathrm{~cm}$ was defined as the reference group. Conditional logistic regression models (Armitage et al, 2001) were calculated to obtain odds ratios (OR) and $95 \%$ confidence intervals (CIs) with and without adjustment for the potentially confounding factor, BMI. The Wald $\chi^{2}$-test was used to test the overall significance of each model parameter.

To identify previous controlled studies of adult height and testicular GCT, a literature survey was performed using electronic search systems (PubMed) and hand search of pertinent literature.

\section{RESULTS}

Analysis revealed that all statistical parameters of height that is, median, minimum, maximum, 25 th percentile and 75 th percentile are greater in patients than in controls (Table 1), whereas the subgroups of seminoma and non-seminoma, showed similar results (Table 1). With respect to height categories, the group ' $180-184 \mathrm{~cm}$ ' is the most frequent in both patients and controls, but those with taller height (i.e. $>185 \mathrm{~cm}$ ) are distinctly more frequent among cases than in controls, as with the subgroups of seminoma and non-seminoma. Conditional regression modelling with body height as the only parameter, given in Table 2 , showed overall significant difference in relative frequencies of height categories between cases and controls $\left(P<0.0001\right.$; Wald $\chi^{2}$-test $)$. There is a significantly increasing risk of GCT with increasing height. As height may conceivably be interrelated with other
Table I Descriptive statistical analysis of height measures $(\mathrm{cm})$

\begin{tabular}{lrccccc}
\hline & n & Min. & 25th pctl & Median & 75th pctl & Max. \\
\hline GCT & 6415 & 150 & 177 & 181 & 186 & 211 \\
Controls & 38490 & 145 & 175 & 180 & 184 & 210 \\
Seminoma & 2667 & 150 & 177 & 182 & 186 & 207 \\
Controls & 16002 & 145 & 175 & 180 & 184 & 210 \\
& & & & & & \\
Non-seminoma & 3748 & 150 & 177 & 181 & 186 & 211 \\
Controls & 22488 & 145 & 175 & 180 & 184 & 208 \\
\hline
\end{tabular}

$\mathrm{GCT}=$ germ cell tumour, $\min .=$ minimum height; $\max .=$ maximum height pctl $=$ percentile.

anthropometric parameters, a descriptive analysis was performed stratifying by BMI categories. As shown in Table 3, patients exceed controls with respect to height in all of the BMI categories indicating that its confounding effect on GCT risk can only be low.

Conditional logistic regression adjusting for BMI confirmed the significant association of height with the risk of GCT (Table 2) and point estimates were almost equal in crude and adjusted models. It can be noted that shorter than average individuals $(<170 \mathrm{~cm})$ were at significantly decreased risk ( $\mathrm{OR}=0.798 ; 95 \% \mathrm{CI}$ : $0.688-0.926)$. Beyond average height, there is an incremental gain in risk with increasing categories of height. Very tall subjects $(>195 \mathrm{~cm})$ have a markedly increased risk ( $\mathrm{OR}=3.35 ; 95 \%$ CI: $2.88-3.903)$. Homogeneous results were obtained after stratification into histological subtypes of GCT (Table 2). The findings were even more distinct when the lowest height category $(<170 \mathrm{~cm})$ was set as a reference in the logistic regression model. Then the highest category $(>195 \mathrm{~cm})$ showed an OR $=4.199$ (95\% CI: $3.452-5.109)$ for GCT overall, and $\mathrm{OR}=4.045$, and $\mathrm{OR}=4.345$ for seminoma and non-seminoma, respectively. Sixteen previous reports on GCT in relation to height were identified, involving a total of 6602 cases.

\section{DISCUSSION}

Our study revealed a strongly significant association of adult height with the risk of testicular GCT. It is unique in three ways: first, it is by far the largest study to date; second, it included the highest risk ever reported; finally, there is a linear trend with increments of height whereas a distinctly decreased risk is found with short stature. The overall relative risk (OR) is 3.35 whereas previous OR ranged from 1.83 to 2.11 (Dieckmann and Pichlmeier, 2002; Swerdlow et al, 1989; McGlynn et al, 2007). It can be noted that GCT patients exceeded controls with respect to all the statistical measures of height, with both histological subgroups of GCT showing similar associations.

The results of the present evaluation are in line with seven previous studies (Kleinteich and Marx, 1983; Gallagher et al, 1995; Dieckmann and Pichlmeier, 2002; Rasmussen et al, 2003; Richiardi et al, 2003; Hardell et al, 2006; McGlynn et al, 2007) encompassing 3098 patients. Nine other studies had failed to demonstrate a significant correlation of body size with GCT risk (Whittemore et al, 1984; Swerdlow et al, 1989; Thune and Lund, 1994; UK Testicular Cancer Study Group, 1994; Davies et al, 1990, 1996; Petridou et al, 1997; Bjørge et al, 2006; Stang et al, 2006). However, it should be noted that three of these investigations found OR of borderline to be nonsignificant (Swerdlow et al, 1989; UK Testicular Cancer Study Group, 1994; Stang et al, 2006), and two disclosed significant associations with only one histological group of GCT (Bjørge et al, 2006; Stang et al, 2006). Importantly, there was no antithethical result. A formal meta-analysis of the abovementioned studies is unfeasible because of the great differences in 
Table 2 Conditional logistic regression with body height as covariate - unadjusted and adjusted for BMI, stratified for all GCT cases, seminoma, and non-seminoma cases

\begin{tabular}{|c|c|c|c|c|c|c|c|c|c|c|c|c|}
\hline Height $(\mathrm{cm})^{\mathrm{a}}$ & \multicolumn{4}{|c|}{ All GCT cases } & \multicolumn{4}{|c|}{ Seminoma cases only } & \multicolumn{4}{|c|}{ Non-seminoma cases only } \\
\hline$<170$ & 0.815 & $0.705-0.941$ & 0.798 & $0.688-0.926$ & 0.882 & $0.707-1.100$ & 0.842 & $0.668-1.059$ & 0.769 & $0.635-0.931$ & 0.764 & $0.629-0.929$ \\
\hline $170-174$ & 0.955 & $0.868-1.050$ & 0.928 & $0.841-1.023$ & 0.943 & $0.811-1.095$ & 0.895 & $0.766-1.047$ & 0.963 & $0.852-1.089$ & 0.946 & $0.834-1.072$ \\
\hline $180-184$ & 1.408 & $1.306-1.519$ & 1.387 & $1.283-1.499$ & 1.417 & $1.260-1.593$ & 1.395 & $1.235-1.576$ & 1.403 & $1.27 \mid-1.548$ & 1.380 & $1.248-1.526$ \\
\hline $185-189$ & 1.542 & $1.419-1.676$ & 1.575 & $1.445-1.717$ & 1.597 & $1.403-1.817$ & 1.641 & $1.433-1.878$ & 1.505 & $1.349-1.678$ & 1.531 & $1.369-1.712$ \\
\hline $190-194$ & 1.979 & $1.781-2.199$ & 2.069 & $1.854-2.309$ & 2.094 & $1.776-2.469$ & 2.232 & $1.876-2.656$ & 1.903 & $1.658-2.184$ & 1.970 & $1.710-2.270$ \\
\hline
\end{tabular}

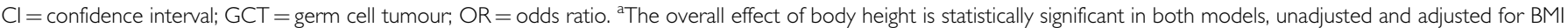
(Wald $\chi^{2}$-test $P<0.000 I$ )

Table 3 Quantitative distribution of body height stratified by BMI category

\begin{tabular}{|c|c|c|c|c|c|c|c|}
\hline BMI $\left(\mathrm{kg} / \mathrm{m}^{2}\right)$ & Pop. & $\mathbf{n}$ & Min. $(\mathrm{cm})$ & 25th pctl $(\mathrm{cm})$ & Median (cm) & 75th pctl $(\mathrm{cm})$ & Max. $(\mathrm{cm})$ \\
\hline 20 to $<25$ & $\begin{array}{c}\text { Controls } \\
\text { Cases }\end{array}$ & $\begin{array}{r}23812 \\
3300\end{array}$ & $\begin{array}{l}148 \\
150\end{array}$ & $\begin{array}{l}175 \\
177\end{array}$ & $\begin{array}{l}180 \\
181\end{array}$ & $\begin{array}{l}184 \\
186\end{array}$ & $\begin{array}{l}210 \\
211\end{array}$ \\
\hline 25 to $<30$ & $\begin{array}{c}\text { Controls } \\
\text { Cases }\end{array}$ & $\begin{array}{l}5327 \\
2062\end{array}$ & $\begin{array}{l}156 \\
150\end{array}$ & $\begin{array}{l}175 \\
177\end{array}$ & $\begin{array}{l}180 \\
181\end{array}$ & $\begin{array}{l}184 \\
186\end{array}$ & $\begin{array}{l}208 \\
204\end{array}$ \\
\hline $30+$ & $\begin{array}{c}\text { Controls } \\
\text { Cases }\end{array}$ & $\begin{array}{r}147 \mid \\
617\end{array}$ & $\begin{array}{l}145 \\
154\end{array}$ & $\begin{array}{l}175 \\
176\end{array}$ & $\begin{array}{l}179 \\
180\end{array}$ & $\begin{array}{l}184 \\
186\end{array}$ & $\begin{array}{l}203 \\
206\end{array}$ \\
\hline
\end{tabular}

$\mathrm{BMI}=$ body mass index; max. = maximum; min. = minimum; $\mathrm{pct}=$ = percentile; pop. = population

design, definition of referent standards and anthropometric categories. Overall, the huge present database in conjunction with the previous studies listed here provides compelling evidence for a virtually existing association of adult height with the risk of GCT.

This study has a number of strengths. The exceptional sample size leaves statistical chance effects at a minimum. Selection bias is unlikely because accrual of patients was performed nation-wide by 228 participating institutions across Germany. Similarly, the control population represented national standard because basically all young German men are enroled by the Federal Army. Confounding by age is ruled out because cases and controls were exactly matched by the day of birth. Conditional logistic regression models were with and without adjusting for BMI. As BMI is mainly associated with energy intake during adulthood, confounding of the present result by nutritional effects after adolescence is improbable. Yet, the study has certain weaknesses, such as controlling only for age and BMI. Anthropometric measures of patients were self-reported for the most part, whereas all of the controls had exactly measured values. As many men overestimate their own height (Blumer, 2007) there may be a systematic bias in the present results, but this is probably only modest. Overestimation of height usually does not exceed $1-2 \mathrm{~cm}$, and mostly only men of short stature will do so. In this study, the proportions of categories with very tall men are distinctly higher among cases than controls, and too great for overestimation bias alone to explain. Moreover, there is some suggestion that overestimation of height is lower in patients than in healthy individuals (McGlynn et al, 2007). Individuals examined during military enrolment at age 18 could have developed GCT in later life. In that event, these individuals would represent grossly inappropriate controls. As, the life-time risk of a German male developing GCT is less than 1\% (Dieckmann and Pichlmeier, 2004), the proportion of controls who might later become affected is far too low to represent a bias.

The association of tallness with testicular cancer risk lends much support to the nutrition hypothesis of GCT pathogenesis. In general, that theory implies an association of nutrition with GCT risk (McGlynn, 2001). As final adult height is largely determined during the first 2 years of life, it may be postulated from the present data that high-calorie nutrition after birth could have promoting or at least conserving effects on GCT precursor cells that are known to evolve during the intra-uterine period (Dieckmann and Pichlmeier, 2004). Direct evidence to support this hypothesis is difficult to establish. However, there are numerous indirect observations in accordance with the theory.

The main observation is the declining incidence rates of GCT in cohorts of men born during World War II or immediately thereafter (Moller, 1993; Bray et al, 2006). In that period malnutrition was common in Europe. When food supply improved some years later incidence rates resumed. The secular trend of increasing adult stature over time has been observed in many countries for many years. Similarly, the incidence rates of GCT have been increasing ever since (Garner et al, 2005; Bray et al, 
2006; Huyghe et al, 2007). Whether or not these two observations are interrelated or just co-existent is unknown because the underlying reasons for both of these developments are obscure. However, what may point to a biological association is the fact that both of the developments could at least partly be explained by the increasing availability of food in the high-incidence nations over time. What also may suggest a true association is the observation that both trends, increasing GCT incidence rates (Pharris-Ciurej et al, 1999) and increasing adult stature (Jaeger et al, 2001), have potentially begun to abate.

Some decades ago, GCT had been found to be more frequent in 'white-collar professions' (Mustacchi and Millmore, 1976). That observation could also fit with the nutrition hypothesis because usually, white-collar professionals belonged to economically privileged classes and food supply was obviously sufficient. Currently, food deficiency is no longer a general problem in Western countries. Conversely, there is a clear trend towards higher prevalence of overweight and obesity, which is predominantly true in lower social classes. Accordingly, social gradients regarding GCT prevalence have levelled off (Pukkala and Weiderpass, 2002; Dieckmann and Pichlmeier, 2004). Overweight has also become a growing problem among Black American citizens (Hedley et al, 2004). In that subpopulation, GCT used to be a rather rare disease (Mustacchi and Millmore, 1976) and it is of particular note that the incidence has recently started to rise markedly (McGlynn et al, 2005).

Two ecological studies support the hypothesis, one showing a correlation between high-fat intake and the incidence of GCT (Armstrong and Doll, 1975) and the other reporting an association of dairy products specifically cheese, with the incidence of testicular cancer (Ganmaa et al, 2002). It is to be noted that, a Swedish cohort study reported an increased risk of GCT for individuals having high cholesterol levels at the edge of adulthood (Wirehn et al, 2005). As serum cholesterol levels may serve as a proxy for high-energy intake, it may be speculated that high fat consumption during childhood may have a bearing on GCT pathogenesis. Four case-control studies supported the connection of GCT risk with dairy food consumption (Davies et al, 1996; Sigurdson et al, 1999; Garner et al, 2003; Stang et al, 2006) whereas three others did not (Bonner et al, 2002; Walcott et al, 2002; McGlynn et al, 2007). Overall, direct evidence by controlled studies to support the nutrition hypothesis of GCT is scarce; however, the bulk of indirect evidence is clearly in favour of the hypothesis.

There is now sufficient evidence to acknowledge tallness as a recognised risk factor of testicular GCT. The underlying biological mechanisms linking tallness and GCT risk are less clear. However, the nutrition hypothesis outlined herein would provide an appealing explanation. According to that hypothesis, high-calorie intake during early childhood could advance length growth and promote GCT precursor cells at the same time. This hypothesis would thus complement and refine the current view of GCT pathogenesis that involves the development of GCT precursor cells during intra-uterine life.

\section{ACKNOWLEDGEMENTS}

This study was supported by grants from Vereinigung Norddeutscher Urologen and Soldatentumorhilfe Hamburg.

\section{REFERENCES}

Albanes D, Jones DY, Schatzkin A, Micozzi MS, Taylor PR (1988) Adult stature and risk of cancer. Cancer Res 48: 1658-1662

Armitage P, Berry G, Matthews JNS (2001) Statistical Methods In Medical Research (4th edn.) Blackwell Scientific: Oxford

Armstrong B, Doll R (1975) Environmental factors and cancer incidence and mortality in different countries, with special reference to dietary practices. Int J Cancer 15: 617-631

Batty GD, Shipley MJ, Langenberg C, Marmot MG, Davey Smith G (2006) Adult height in relation to mortality from 14 cancer sites in men in London (UK): evidence from the original Whitehall study. Ann Oncol 17: $157-166$

Bjørge T, Tretli S, Lie AK, Engeland A (2006) The impact of height and body mass index on the risk of testicular cancer in 600000 Norwegian men. Cancer Causes Control 17: 983-987

Blumer I (2007) Do you really know how tall you are? Can Med Assoc J 176: 66

Bonner MR, McCann SE, Moysich KB (2002) Dietary factors and the risk of testicular cancer. Nutr Cancer 44: 35-43

Bray F, Ferlay J, Devesa SS, McGlynn KA, Moller H (2006) Interpreting the international trends in testicular seminoma and nonseminoma incidence. Nat Clin Pract Urol 3: 532-543

Davies TW, Palmer CR, Ruja E, Lipscombe JM (1996) Adolescent milk, dairy product and fruit consumption and testicular cancer. Br J Cancer 74: $657-660$

Davies TW, Prener A, Engholm G (1990) Body size and cancer of the testis. Acta Oncol 29: 287-290

Dieckmann KP (2007) Pre- and paraclinical cooperative trials on testicular cancer: background and overview of current trials. (article in German). Urologe A 46: 1180 - 1184

Dieckmann KP, Pichlmeier U (2002) Is risk of testicular cancer related to body size? Eur Urol 42: $564-569$

Dieckmann KP, Pichlmeier U (2004) Clinical epidemiology of testicular germ cell tumors. World J Urol 22: $2-14$

Dieckmann KP, Skakkebaek NE (1999) Carcinoma in situ of the testis: a review of biological and clinical features. Int J Cancer 83: 815-822
Ehrengut W, Schwartau M, Hubmann R (1980) Testikuläre Vorerkrankungen bei Patienten mit Hodentumoren unter besonderer Berücksichtigung der Mumpsorchitis. Urologe A 19: 283-288

Gallagher RP, Huchcroft S, Phillips N, Hill GB, Coldman AJ, Coppin C, Lee T (1995) Physical activity, medical history, and risk of testicular cancer (Alberta and British Columbia, Canada). Cancer Causes Control 6: $398-406$

Ganmaa D, Li XM, Wang J, Qin LQ, Wang PY, Sato A (2002) Incidence and mortality of testicular and prostatic cancers in relation to world dietary practices. Int J Cancer 98: 262 -267

Garner MJ, Birkett NJ, Johnson KC, Shatenstein B, Ghadirian P, Krewski D (2003) Dietary risk factors for testicular carcinoma. Int J Cancer 106: 934-941

Garner MJ, Turner MC, Ghadirian P, Krewski D (2005) Epidemiology of testicular cancer: an overview. Int J Cancer 116: 331 -339

Giovannucci E, Rimm EB, Liu Y, Willett WC (2004) Height, predictors of C-peptide and cancer risk in men. Int J Epidemiol 33: 217-225

Gunnell D, Okasha M, Smith GD, Oliver SE, Sandhu J, Holly JM (2001) Height, leg length, and cancer risk: a systematic review. Epidemiol Rev 23: $313-342$

Hardell L, Bavel B, Lindstrom G, Eriksson M, Carlberg M (2006) In utero exposure to persistent organic pollutants in relation to testicular cancer risk. Int J Androl 29: 228-234

Hedley AA, Ogden CL, Johnson CL, Carroll MD, Curtin LR, Flegal KM (2004) Prevalence of overweight and obesity among US children, adolescents, and adults, 1999-2002. JAMA 291: 2847-2850

Hoei-Hansen CE, Rajpert-De Meyts E, Daugaard G, Skakkebaek NE (2005) Carcinoma in situ testis, the progenitor of testicular germ cell tumours: a clinical review. Ann Oncol 16: $863-868$

Huyghe E, Plante P, Thonneau PF (2007) Testicular cancer variations in time and space in Europe. Eur Urol 51: 621-628

Jaeger U, Zellner K, Kromeyer-Hauschild K, Lüdde R, Eisele R, Hebebrand J (2001) Körperhöhe, Körpergewicht und body mass index bei deutschen Wehrpflichtigen. Historischer Rückblick und aktueller Stand. Anthrop Anz 59: $251-273$ 
Kleinteich B, Marx G (1983) Sind große schlanke Männer für Hodenkarzinome disponiert? Med Akt 9: 146

McGlynn KA (2001) Environmental and host factors in testicular germ cell tumors. Cancer Invest 19: 842 - 853

McGlynn KA, Devesa SS, Graubard BI, Castle PE (2005) Increasing incidence of testicular germ cell tumors among black men in the United States. J Clin Oncol 23: 5757-5761

McGlynn KA, Sakoda LC, Rubertone MV, Sesterhenn IA, Lyu C, Graubard BI, Erickson RL (2007) Body size, dairy consumption, puberty, and risk of testicular germ cell tumors. Am J Epidemiol 165: 355-363

Mensink GBM, Lampert T, Bergmann E (2005) Overweight and obesity in Germany 1984-2003. Bundesgesundheitsbl Gesundheitsforsch Gesundheitsschutz 48: 1348 - 1356

Moller H (1993) Clues to the aetiology of testicular germ cell tumours from descriptive epidemiology. Eur Urol 23: 8-13

Mustacchi P, Millmore D (1976) Racial and occupational variations in cancer of the testis: San Francisco,1956-65. J Natl Cancer Inst 56: 717-720

Petridou E, Roukas KI, Dessypris N, Aravantinos G, Bafaloukos D, Efraimidis A, Papacharalambous A, Pektasidis D, Rigatos G, Trichopoulos D (1997) Baldness and other correlates of sex hormones in relation to testicular cancer. Int I Cancer 71: $982-985$

Pharris-Ciurej ND, Cook LS, Weiss NS (1999) Incidence of testicular cancer in the United States: has the epidemic begun to abate? Am J Epidemiol 150: $45-46$

Pukkala E, Weiderpass E (2002) Socio-economic differences in incidence rates of cancers of the male genital organs in Finland, 1971-95. Int J Cancer 102: $643-648$

Rasmussen F, Gunnell D, Ekbom A, Hallqvist J, Tynelius P (2003) Birth weight, adult height, and testicular cancer: cohort study of 337,249 Swedish young men. Cancer Causes Control 14: 595-598
Richiardi L, Askling J, Granath F, Akre O (2003) Body size at birth and adulthood and the risk for germ-cell testicular cancer. Cancer Epidemiol Biomarkers \& Prev 12: 669-673

Sigurdson AJ, Chang S, Annegers JF, Duphorne CM, Pillow PC, Amato RJ, Hutchinson LP, Sweeney AM, Strom SS (1999) A case-control study of diet and testicular carcinoma. Nutr Cancer 34: 20-26

Sinclair D, Dangerfield P (1998) Human Growth After Birth 6th (edn) Oxford University Press: London

Stang A, Ahrens W, Baumgardt-Elms C, Stegmaier C, Merzenich H, de Vrese M, Schrezenmeir J, Jockel KH (2006) Adolescent milk fat and galactose consumption and testicular germ cell cancer. Cancer Epidemiol Biomarkers Prev 15: 2189-2195

Swerdlow AJ, Huttly SRA, Smith PG (1989) Testis cancer: post-natal hormonal factors, sexual behaviour and fertility. Int $J$ Cancer 43: $549-553$

Thune I, Lund E (1994) Physical activity and the risk of prostate and testicular cancer: a cohort study of 53000 Norwegian men. Cancer Causes Control 5: $549-556$

UK Testicular Cancer Study Group (1994) Social, behavioural and medical factors in the aetiology of testicular cancer: results from the UK study. Br J Cancer 70: 513-520

Walcott FL, Hauptmann M, Duphorne CM, Pillow PC, Strom SS, Sigurdson AJ (2002) A case-control study of dietary phytoestrogens and testicular cancer risk. Nutr Cancer 44: 44-51

Whittemore AS, Paffenbarger RSJ, Anderson K, Lee JE (1984) Early precursors of urogenital cancers in former college men. J Urol 132: $1256-1261$

Wirehn AB, Tornberg S, Carstensen J (2005) Serum cholesterol and testicular cancer incidence in 45000 men followed for 25 years. $\mathrm{Br} J$ Cancer 92: 1785 - 1786 